\title{
Estimated Body Weight
}

National Cancer Institute

\section{Source}

National Cancer Institute. Estimated Body Weight. NCI Thesaurus. Code C132482.

An approximate determination of the weight of a body. 